\title{
Presentation
}

\author{
HIV 予防のグローバル戦略とワクチン開発への期待 \\ 田沼順子
}

Published online 24 May, 2014

\section{Global Efforts against HIV Epidemic and HIV Vaccine Development}

\author{
Junko Tanuma
}

\begin{abstract}
Although the tremendous effort has been paid by scientists for creating HIV vaccine over the past three decades since the discovery of HIV-1, the HIV vaccine development still has a long way to go. Only one HIV vaccine, RV144, has been proved to be moderately effective by the clinical trials, but there has been much debate about its usefulness. The difficulties of HIV vaccine development includes the attacks to host's immune system by HIV and the emergence of various escape mutants. The necessity of large clinical trials for the proof of efficacy also makes HIV vaccine development difficult.

One the other hand, Treatment as Prevention (TasP) or Preexposure Prophylaxis (PrEP) has revealed to be highly effective for HIV prevention.

Those preventive strategies using antiretroviral therapy is one of the recent main stream of HIV policy worldwide. However, it is believed that a sustained end of the HIV pandemic is guaranteed by the combination of nonvaccine prevention and the development of a safe and effective HIV vaccine. The continuous efforts are needed for the HIV vaccine development.

Key words: HIV, Treatment as Prevention, PrEP
\end{abstract}

\section{はじめに}

抗レトロウイルス療法（antiretroviral therapy: ART）は 開発途上国においても急速に普及しつつあり，HIV 感染 者は広く長期生存が可能となったため, 全体の感染者数 は増加している。しかし, 新規 HIV 感染者は年間 200 万 人に減少しつつある（Fig. 1）［1］。このような変化がも たらされた背景と, ワクチン開発の現状を総括したい。

\section{Treatment as Prevention}

HPTN052 試験［2］は 2005 年に始まった Randomized Controlled Trial（RCT） で，アフリカ 5 カ国とブラジル, インド, タイ, 米国の 18 歳以上の, どちらかが HIV 陽 性で一方が HIV 陰性 (HIV discordant) のカップル計 1763 組（97\%が異性間カップル）が参加した。直ちに HIV 治

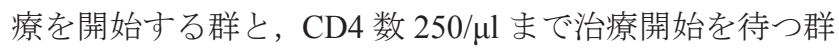
で $1: 1$ に割り付けされ, その後のカップル内の感染率が
比較された。2015 年まで続けられる予定であったが，中 間報告において治療をすぐに開始した群では 1 組, 治療 を遅らせた群では 27 組のカップル内 HIV 感染が確認さ

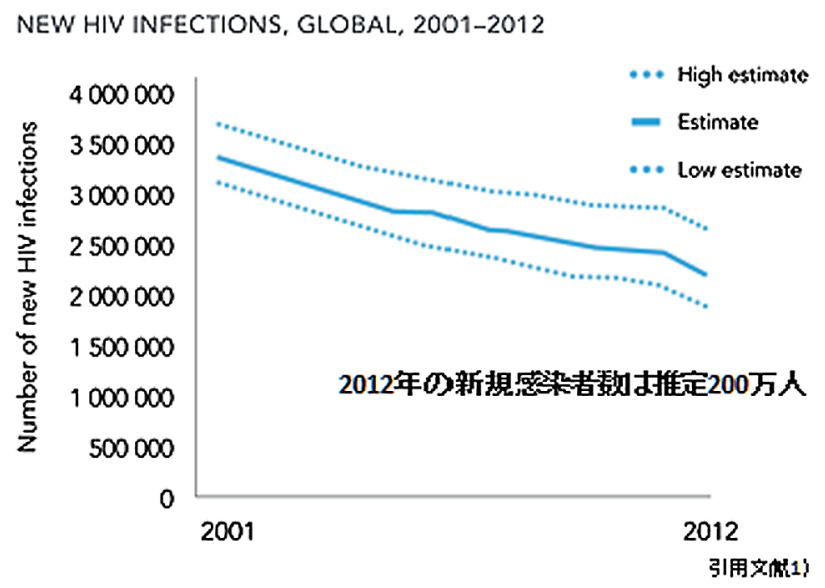

Fig. 1.世界の新規 HIV 感染者数は減少傾向にある

国立国際医療研究センターエイズ治療・研究開発センター（† 162-8655 東京都新宿区戸山 1-21-1）

AIDS Clinical Center, National Center for Global Health and Medicine, 1-21-1 Toyama, Shinjuku, Tokyo 162-8655, Japan Tel: +81-3-3202-7181 (ext 5642)

Fax: +81-3-5278-6483

E-mail: jtanuma@acc.ncgm.go.jp 
れ, 両群の感染率に大きな差が出たため 2011 年で打ち切 られて結果が公表された。感染予防としての cARTの意 義を明らかにした画期的な臨床試験であり, Science 誌の Breakthrough of the Year 2011 に選出された。その画期的 成果に対する世界の反応は早く, 現在すでに感染者に対 する早期治療（Treatment as Prevention）は世界の HIV 予 防戦略の中心となっている。加えて, 最近暴露前予防 (Pre-exposure Prophylaxis: PrEP) の有効性も明らかとなっ てきている。このような ART を効果的に使う手法 [3-6] は, 実用化が進まない予防ワクチンにかわって, 有望な 感染拡大阻止策として重要視されている。

\section{予防ワクチン開発}

HIV が宿主の免疫応答そのものを利用して増殖するこ とや，様々な防御免疫へのエスケープ変異を獲得すしや すいことがワクチン開発の大きな壁となっている。他に も, 多くの地域特有の流行株, 動物モデルの限界, 資源 の限られた国でも使用可能な安価なワクチンが求められ ること, 大規模な臨床試験が必要なこと等, 様々な課題 が挙げられる。しかし予防ワクチン開発への期待が途切 れた訳では決してない。これまでに臨床的に有効性が証 明された唯一の予防ワクチンである RV144［3］は，タ イでの臨床試験で $31.2 \%$ 感染阻止効果があったという。 RV144の効果はまだ実用化に十分とはいえないが，この 研究で今後の開発に寄与寸る様々な知見が得られている。 また，ここ数年間, 広範囲な株に対して有効な中和抗体 (Broadly neutralizing antibody) が, 複数発見され, 中和抗 体を誘導するワクチンが見直されてきている。

$$
\text { おおりに }
$$

ワクチンや ART を使った予防策の感染減少効果を Fig. 2 に示す。このように，多くの研究者による絶え間 ない努力をもってしても，未だ実用化に至った HIV 予防 ワクチンがない一方, 予防としての治療が確立されつつ あるのが現状である。しかし，予防的治療だけで「エイ ズなき世代」を実現することは難しいと考えられており， 日本発のものを含めワクチン候補はまだ多数あることか

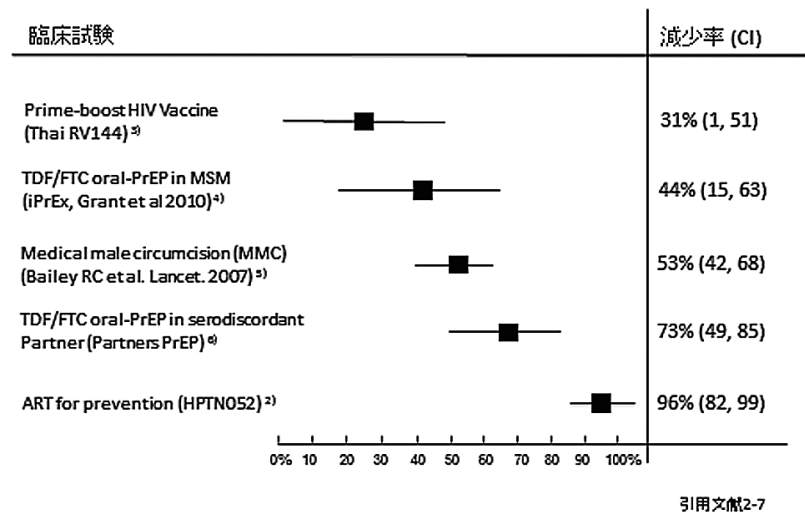

Fig. 2. RV144 ワクチンと抗レトロウイルス薬の感染率減 少効果

ら，今後の研究の成果に大いに注目したい。

\section{文 献}

1. UNAIDS report on the global AIDS epidemic 2013. Sep 24, 2013.

2. Cohen MS, Chen YQ, McCauley M, Gamble T, Hosseinipour MC, Kumarasamy N, Hakim JG, Kumwenda J, Grinsztejn B, Pilotto JH, et al. Prevention of HIV-1 Infection with Early Antiretroviral Therapy. N Engl J Med 2011; 365: 493-505.

3. Rerks-Ngarm S, Pitisuttithum $\mathrm{P}$, Nitayaphan $\mathrm{S}$, Kaewkungwal J, Chiu J, Paris R, Premsri N, Namwat C, de Souza M, Adams E, et al. Vaccination with ALVAC and AIDSVAX to Prevent HIV-1 Infection in Thailand. N Engl J Med 2009; 361: 2209-2220.

4. Grant RM, Lama JR, Anderson PL, McMahan V, Liu AY, Vargas L, Goicochea P, Casapía M, Guanira-Carranza JV, Ramirez-Cardich ME, et al. Preexposure Chemoprophylaxis for HIV Prevention in Men Who Have Sex with Men. N Engl J Med 2010; 363: 2587-2599.

5. Bailey RC, Moses S, Parker CB, Agot K, Maclean I, Krieger JN, Williams CF, Campbell RT, Ndinya-Achola JO. Male circumcision for HIV prevention in young men in Kisumu, Kenya: a randomised controlled trial. Lancet 2007; 369: 643-656.

6. Baeten JM, Donnell D, Ndase P, Mugo NR, Campbell JD, Wangisi J, Tappero JW, Bukusi EA, Cohen CR, Katabira E, et al. Antiretroviral prophylaxis for HIV prevention in heterosexual men and women. N Engl J Med 2012; 367: $399-410$. 